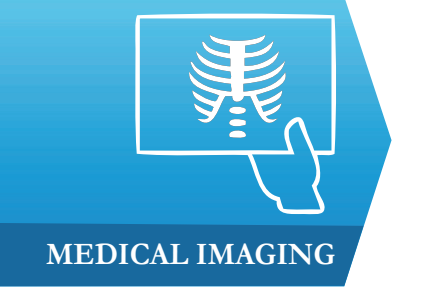

\section{Diagnostic yield of endoscopic ultrasound- guided biopsy of focal liver lesions}

Vlad Andrei Ichim, Romeo Ioan Chira, Petru Adrian Mircea
Department of Internal Medicine. Division of Gastroenterology, Iuliu Hatieganu University of Medicine and Pharmacy, Cluj-Napoca, Romania
DOI: $10.15386 /$ cjmed-1066

Manuscript received: 15.05 .2018 Received in revised form: 25.07 .2018 Accepted: 08.08.2018

Address for correspondence: ichimvlad@gmail.com

\begin{abstract}
Endoscopic ultrasonography (EUS) has become an indispensable method for diagnosis and therapeutic procedures in gastroenterology. As experience with this technique grows, new indications continue to emerge. Due to the vicinity of the transducer to the liver, endoscopic ultrasonography provides detailed images of the liver segments and its vascular and biliary structures. Endosonographers have made an effort to define a clinical role for endoscopic ultrasound in liver diseases; however, not much is known about endoscopic ultrasound guided fine needle aspiration (EUSFNA) in hepatic focal lesions.

This review summarizes the available evidence regarding the usefulness of endoscopic ultrasound-guided fine needle aspiration in patients with focal liver lesions.
\end{abstract}

Keywords: EUS-FNA, liver biopsy, focal liver lesions

\section{Introduction}

Endoscopic ultrasonography (EUS) has become an indispensable method for diagnosis and therapeutic procedures in gastroenterology and as experience with this technique is growing, new indications for EUS continue to emerge [1].

There has been continuous progress in EUS diagnostic capabilities warranted by improved imaging systems, more suitable needles that resulted in better tissue sampling and lower technical failure rate [2-8], and also the development of enhanced imaging functions such as contrast harmonic and elastography $[9,10]$.

The prospect to obtain precise, ultrasound-guided biopsies of possible metastatic liver lesions can drastically alter the therapeutic conduct $[11,12]$. This, combined with limited adverse events [13], makes EUS an excellent modality to allow staging in malignant conditions. Due to the vicinity of the transducer to the liver, EUS provides detailed images of the liver segments and its vascular structures [14-16]. Consequently, endosonographers have made an effort to define a clinical role for EUS in liver diseases; however, not much is known about EUS-FNA in hepatic focal lesions. Still, there is a limited number of articles that analyze the role of EUS guided FNA for focal liver lesions. The objective of this paper was to evaluate the available evidence regarding the usefulness of endoscopic ultrasoundguided fine needle aspiration (EUS-FNA) in patients with focal liver lesions.

\section{Material and method}

A systematic review was conducted in order to assess the evidence supporting the diagnostic yield of endoscopic ultrasound-guided biopsy of focal liver lesions and how it applies in daily clinical practice. We conducted a PubMed search using "endoscopic ultrasound liver biopsy" and "endoscopic ultrasound liver FNA" key concepts. We screened the titles and the abstracts for eligibility and all articles relevant to the subject were extracted up to March 2018. Moreover, the references of reviewed articles were analyzed in order to obtain any other reference that eluded the primary search. Non-English language articles, commentaries, letters, congress proceedings, abstracts, and articles in which EUS did not represent the major focus were not included. The full-texts of the relevant studies that were identified were assessed using our inclusion and exclusion criteria and finally 9 studies were included in the analysis. 
Regarding data collection, considering the small number of studies on the topic, priority was assigned to the study subject, not taking into consideration the type and year of publication or the number of patients enrolled. The content of each study was further analyzed to identify relevant clinical issues. The extracted data included the name of the author, the year of publishing, the study design, the needle size used for the FNA procedure, the diagnostic adequacy and complication rate.

\section{Results}

Search strategy with keywords "endoscopic ultrasound liver biopsy" and "endoscopic ultrasound liver FNA" returned 1341 results. Abstracts were all screened by (IV) and the full text of relevant articles was retrieved and analyzed. Finally 9 studies were included in the analysis.
Characteristics of the included studies are displayed in Table I. The 9 studies included in our analysis enrolled 1207 patients of which 414 underwent EUS-FNA.

Common focal liver lesions include hepatocellular carcinoma, cholangiocarcinoma, metastasis, focal nodular hyperplasia, adenoma, hemangioma, regenerative nodular hyperplasia, biliary cystadenoma, and simple liver cyst. The precise diagnosis of hepatic masses is imperative for clinical decision-making. Many of these lesions can be diagnosed by standard abdominal imaging alone or combined with percutaneous biopsy [16]. However, smaller lesions, less than $1-2 \mathrm{~cm}$ in diameter may not be diagnosed adequately by abdominal ultrasound, computed tomography, magnetic resonance imaging or may not be reachable for percutaneous biopsy [21,24-26].

Table I. Diagnostic yield of endoscopic ultrasound-guided biopsy of focal liver lesions.

\begin{tabular}{|c|c|c|c|c|c|}
\hline Reference & \begin{tabular}{|c|} 
Study design \\
Patients/EUS-FNA
\end{tabular} & $\begin{array}{l}\text { Needle } \\
\text { (G) }\end{array}$ & $\begin{array}{c}\text { Diagnostic adequacy } \\
{[\%]}\end{array}$ & $\begin{array}{c}\text { Complications } \\
{[\%]}\end{array}$ & Particularity \\
\hline $\begin{array}{l}\text { Nguyen et al } \\
1999[11]\end{array}$ & $\begin{array}{l}\text { Prospective } \\
\text { Single center } \\
574 / 14\end{array}$ & 22 & 100 & none & $\begin{array}{c}\text { Before EUS, computer tomography } \\
\text { detected liver lesions in only } 3 \text { of } 14(21 \%) \text { patients. }\end{array}$ \\
\hline $\begin{array}{l}\text { tenBerge et al } \\
2002[13]\end{array}$ & $\begin{array}{l}\text { Retrospective } \\
\text { Multicenter } \\
167 / 167\end{array}$ & & 96 & 4 & $\begin{array}{l}\text { EUS-FNA of focal liver lesion diagnosed malignancy } \\
\text { when CT-FNA failed to do so in } 83 \% \text { of the cases }\end{array}$ \\
\hline $\begin{array}{l}\text { DeWitt et al } \\
2003[17]\end{array}$ & $\begin{array}{l}\text { Prospective } \\
\text { Single center } \\
77 / 77\end{array}$ & 22 & 82 to 94 & none & $\begin{array}{l}\text { EUS detected the malignancy in } 41 \% \text { of patients with } \\
\text { previously negative US/CT examinations }\end{array}$ \\
\hline $\begin{array}{l}\text { Hollerbach } \\
\quad \text { et al } \\
2003[18]\end{array}$ & $\begin{array}{l}\text { Prospective } \\
\text { Single center } \\
\quad 41 / 41\end{array}$ & 22 & 94 & 2.5 & $\begin{array}{c}\text { Malignant lesions were correctly identified by cytology in } \\
73 \% \text { of the patients, while by histology in } 82 \% \text {. } \\
\text { When both modalities combined } 94 \% \text { of malignancies } \\
\text { were correctly diagnosed. }\end{array}$ \\
\hline $\begin{array}{l}\text { McGrath et al } \\
2005 \text { [19] }\end{array}$ & $\begin{array}{l}\text { Prospective } \\
\text { Single center } \\
\quad 98 / 5\end{array}$ & 22 & 80 & none & $\begin{array}{c}\text { These lesions were not evident on prior } \\
\text { noninvasive imaging }\end{array}$ \\
\hline $\begin{array}{l}\text { Crowe et al } \\
2005[20]\end{array}$ & $\begin{array}{l}\text { Retrospective } \\
\text { Single center } \\
50 / 16\end{array}$ & 22 & $\begin{array}{l}\text { benign } 19 \\
\text { atypical } 25 \\
\text { malignant } 56\end{array}$ & & $\begin{array}{l}\text { CT-FNA and EUS-FNA yielded a similar range of benign, } \\
\text { atypical and malignant diagnoses (CT: } 26 \%, 18 \% \text {, and } \\
56 \% \text { vs. EUS: } 19 \%, 25 \% \text {, and } 56 \%)\end{array}$ \\
\hline $\begin{array}{l}\text { Sing et al } \\
2009[21]\end{array}$ & $\begin{array}{l}\text { Prospective } \\
\text { Single center } \\
132 / 26\end{array}$ & 22 & 98 & none & $\begin{array}{l}\text { The diagnostic accuracy of EUS/EUS-FNA and CT scan } \\
\text { was } 98 \% \text { and } 92 \% \text {, respectively } \\
\text { In comparison to CT scan, EUS detected significantly } \\
\text { higher number of metastatic lesions in the liver (40vs19). } \\
\text { CT scan detected lesions in liver that were too small to } \\
\text { be characterized in } 8 \text { cases (malignant } 3 \text {; benign } 5 \text { ). Of } \\
\text { these, EUS-FNA correctly characterized the lesion to be } \\
\text { malignant in } 3 / 3 \text { cases and benign in } 4 / 5 \text { cases }\end{array}$ \\
\hline $\begin{array}{l}\text { Lee et al } \\
2016[22]\end{array}$ & $\begin{array}{l}\text { Prospective } \\
\text { Single center } \\
21 / 21\end{array}$ & $\begin{array}{l}\text { stomach } \\
22 \\
\text { duodenum } \\
25\end{array}$ & 85.7 & none & $\begin{array}{l}\text { The EUS-FNB for liver solid mass were performed for } \\
\text { patients in where percutaneous method failed to acquire a } \\
\text { tissue or achieve a diagnosis }\end{array}$ \\
\hline $\begin{array}{l}\text { Oh D. et al } \\
2017[23]\end{array}$ & $\begin{array}{c}\text { Observational } \\
\text { Single center } \\
47 / 47\end{array}$ & $22 / 25$ & 90.5 & none & $\begin{array}{l}\text { Diagnostic accuracy for liver masses was not different } \\
\text { between left and right lobe }\end{array}$ \\
\hline
\end{tabular}




\section{Discussion}

\section{Basic principles of EUS-FNA of the liver}

EUS can chart the detailed anatomy of the liver from transgastric and transduodenal routes. Viewing and sampling the right posterior segments is laborious but achievable $[23,27]$. In addition, EUS offers the potential for a precise biopsy for histology/cytology examination. Still, the role of EUS-guided FNA in the diagnosis of liver lesions has not been standardized at this point [28].

When performing the EUS-FNA/FNB procedure, the target lesion is visualized using a linear echoendoscope and interposed vessels are excluded with the help of color Doppler. Under real time ultrasound guidance, the lesion is punctured and sampled with or without vacuum suction by a series of needle passes within the target lesion (fanning technique) $[29,30]$. The use of stylet during FNA does not appear to confer any advantage with regards to the adequacy of the specimen or diagnostic yield of malignancy [31]. The aspirate acquired is then laid out onto glass slides for cytology smears or immersed in formalin for histology. Rapid on-site cytological examination (ROSE) by a cytologist may help, in real-time, to assess cytological smear adequacy, but this adds to procedural costs and is scarcely available $[29,30]$. Although diagnostic accuracy achieved by cytology suffices in most instances, tissue histology seems to be the preferred option in specific circumstances that requires tissue architecture as part of the assessment or ancillary tests such as immunohistochemical studies and molecular analysis [32].

EUS-FNB gained support with the emergence of EUS core biopsy needles, over a decade ago. Initially, it fell short showing superiority over traditional FNA, and the technical failure rate was high [33]. Later, softer, more flexible needles developed and they are being increasingly used for tissue acquisition. Currently, there is a variety of EUS-FNB needles available, with sizes ranging from 19 to 25 gauge. These needles are easier to use and increase the rate of core tissue acquisition, therefore reduce the need for ROSE [3-8,34,35].

\section{EUS compared to CT/MRI for detection of focal liver mass}

Hepatic metastasis is commonly hypoechoic, with an uneven border such as the one seen in pancreatic and colon metastasis or hyperechoic such as seen in metastatic neuroendocrine tumors and renal cell carcinoma [36,37]. Hepatocellular carcinoma may occur on EUS images either as hypoechoic or hyperechoic [38].

Starting from the premise that EUS is more sensitive for the detection of small hepatic lesions then CT/MRI, Singh et al. compared the accuracy of EUS with CT and MRI in 2 different studies. In one study EUS proved to be superior to CT scan in diagnostic accuracy, $98 \%$ vs $92 \%$, respectively, $(\mathrm{P}=0.0578)$ and in its ability to detect the number of metastatic lesions in the liver, 40 vs 19 , respectively, $(P=0.008)$. In eight cases, CT detected lesions that were too small to characterize, of which EUS-
FNA correctly diagnosed three cases to be malignant and four cases to be benign [21]. In the second study, EUS/ EUS-FNA had a diagnostic accuracy of $94 \%$ and exceeded the diagnostic accuracy of US, CT or MRI $(38 \%, 69 \%$, and $92 \%)$. EUS also detected a significantly higher number of nodular lesions compared to US $(\mathrm{P}=0.03), \mathrm{CT}(\mathrm{P}=0.002)$ and MRI $(\mathrm{P}=0.04)$ [24].

Burrel et al. revealed that smaller lesion, under $1 \mathrm{~cm}$ in diameter, can be missed in a significant percentage (70\%) of patients by CT imaging and MRI [25]. Awad et al. evaluated the utility of EUS in detecting and diagnosing hepatic masses and established that EUS successfully identified hepatic lesions ranging from 3-14 mm, previously undetected by dynamic CT scans [26].

Diagnostic yield of EUS-FNA of focal liver lesions

EUS-FNA may be useful in the diagnosis of focal liver lesions, metastatic lesions, early hepatocellular carcinoma, and evaluation of perihepatic adenopathy [3640] but there are only a few studies that evaluate tissue quality, diagnostic accuracy and different needle types for EUS-FNA of the liver.

Initial data on EUS-FNA of the liver came from Nguyen et al. in 1999. The authors concluded that EUS can detect small focal liver lesions not detected by CT, and EUS-FNA can confirm a cytologic diagnosis of liver metastasis and establish a definitive $M$ stage that may change the clinical management [11].

tenBerge et al. used EUS-FNA to determine indications, yield, and safety based on an international survey of 167 cases. For the 167 EUS-FNA procedures, the findings of the cytopathology were malignancy in $138(83 \%)$, benign in $22(13 \%)$, and indeterminate in $7(4 \%)$. EUS-FNA was performed after CT guided FNA in 7 cases. In 83\% (5/6) EUS-FNA of the liver diagnosed malignancy when CTguided liver FNA failed to do so. The authors concluded that EUS-FNA should be considered when a hepatic lesion is poorly accessible by US/CT-guided FNA [13].

In a retrospective study by DeWitt et al., EUS-FNA of the liver was performed in 77 patients. Of these lesions, $58 \%$ were diagnostic for malignancy, $33 \%$ were benign, and $9 \%$ were nondiagnostic. The sensitivity of EUS-FNA for malignancy ranged $82-94 \%$ depending on whether the seven nondiagnostic specimens were actually malignant or benign. EUS-FNA detected malignant liver tumors that were not described by CT or US (or both) in $41 \%$ of cases. When compared to benign lesions, the authors found that malignant lesions detected by EUS-FNA were more likely to have regular margins $(60 \%$ vs $27 \%$; $=0.02)$ and to be accompanied by at least one other lesion detected on EUS $(38 \%$ vs $9 \% ; p=0.03)$ [17].

In a prospective study conducted by Hollerbach et al., EUS-FNA provided appropriate biopsy specimens in $40 / 41$ patients. With regard to malignancy, the combination of histology and cytology had a sensitivity of $94 \%$ and specificity of $100 \%$, with a negative predictive value of 
$78 \%$ and positive predictive value of $100 \%$. Malignant lesions were correctly identified by cytology alone in $73 \%$ of patients, while histology alone was diagnostic in $83 \%$ of patients. The study concludes that the best diagnostic results come from combining cytology and histology but taking into consideration that negative results do not rule out malignant disease and the procedure should be repeated if clinically required [18].

While performing EUS for esophageal cancer staging, McGrath et al. detected occult left hepatic lobe metastases in $7 \%$ of fully staged cases. None of these metastases were described on noninvasive staging examinations. The sensitivity of EUS-FNA for occult left hepatic lobe metastases was $80 \%$ [19].

Crowe et al. compared the results of 34 CT-FNA and 16 EUS-FNA of focal liver lesions. In both groups of patients the primary clinical indication for FNA was suspected metastatic carcinoma. The 2 techniques yielded a similar range of benign, atypical, and malignant diagnoses CT( $26 \%, 18 \%$, and $56 \%)$ vs. EUS( $19 \%, 25 \%$, and $56 \%)$. Nine of the 16 EUS-FNA of the liver procedures involved simultaneous sampling of pancreatic masses. In those cases the primary diagnosis of pancreatic carcinoma was established and meaningful staging data were obtained in a single diagnostic encounter. One case involved concurrent staging of pulmonary carcinoma by sampling a lymph node and the liver during a single endoscopic procedure. The data from this study demonstrates the versatility of the EUS approach in diagnosing malignancy [20].

Lee et al. evaluated the role of EUS-FNA of solid liver mass as a percutaneous biopsy rescue method. EUSFNA was performed to 21 patients who priorly underwent percutaneous liver biopsy with failure to sample (because of poor accessibility or invisibility of the lesion by US) or achieve histologic diagnosis. In 19/21 (90.5\%) of the patients, malignancy was diagnosed by EUS-FNA [22].

Outset from the premise that the right liver lobe is more difficult to visualize by EUS, Oh D et al. sought to evaluate the efficacy of EUS-FNA in patients with liver masses including the right lobe. Tissue acquisition was successful in $97.9 \%(46 / 47)$. EUS-FNA was diagnostic in 38 of 42 patients $(90.5 \%)$. Specimens were acquired from the left lobe in 30 patients $(63.8 \%)$ and the right lobe in 17 patients (36.2\%). Concerning the differences between right liver mass and left mass, adequate specimen obtained was statistically higher in the left lobe $(28 / 30,93.3 \%$ vs. $14 / 17$, $82.4 \%, P=0.04)$. However, diagnostic accuracy for liver masses was not different $(25 / 28,89.3 \%$ vs. $13 / 14,92.9 \%$, $P=0.86$ ) [22].

These studies and others suggest that EUS-FNA is at least comparable if not superior to US/CT-guided biopsy in the diagnosis of patients with focal liver lesions.

\section{Complications and limitations}

EUS has an acceptable overall safety profile. Nonetheless, there are notable complications, perforation being the most serious of them $[41,42]$. However, the majority of complications related to EUS take place during EUS-FNA and include infection, hemorrhage, bile peritonitis and exceptionally malignant seeding [43]. A systematic review reported the mortality associated with EUS and EUS-FNA is $0.02 \%$ while the overall rate of EUSFNA-specific morbidity was $0.98 \%$ [44]. There is little difference between EUS-FNA and EUS-FNB regarding complication rates [45]. A meta-analysis that included 51 studies failed to demonstrate a statistical difference in rate of adverse events associated with $19 \mathrm{G}$ needles as compared to $22 \mathrm{G} / 25 \mathrm{G}$ needles [46].

As to EUS liver FNA in particular, there were no adverse events reported in 6 out of the 9 studies included in the analysis [11,17,19,21-23]. tenBerge reported complications in 6 patients (4\%) from which 1 death (suspected to have an occluded biliary stent at the time of EUS), 1 bleeding, 2 cases of postprocedural fever and 2 cases of postprocedural abdominal pain [13].

EUS-FNA of the liver has certain limitations. The presence of vascular structures in the path of the needle may limit the access to the lesion. Because the right liver lobe is farther away from the transducer, it is generally harder to examine and biopsy but EUS procedure is still feasible [23]. Nevertheless, with improving resolution, use of Doppler, elastography [9], harmonic imaging, contrast enhancement [10] have improved the accuracy of the procedure.

\section{Conclusions}

Endoscopic ultrasound-guided fine needle aspiration/biopsy of focal liver lesions is practical, safe, and provides a high diagnostic accuracy. With recent advancements in EUS, it has shown superiority in detecting focal liver lesions as compared to conventional CT scan and ultrasound imaging modalities and combined with the ability to acquire tissue samples it proves to be an extremely useful tool.

It is reasonable to conclude that EUS-FNB with core biopsy needle for solid liver masses may be helpful in the management of a subset of patients for whom the percutaneous approach fails. However, it does not mean EUS-FNB can replace totally percutaneous biopsy. Therefore, we need further study to establish algorithms for deciding which modality is more effective for each patient.

\section{References}

1. Saraireh HA, Bilal M, Singh S. Role of endoscopic ultrasound in liver disease: Where do we stand in 2017? World J Hepatol. 2017;9:1013-1021.

2. Ang TL, Kwek ABE, Wang LM. Diagnostic Endoscopic Ultrasound: Technique, Current Status and Future Directions. Gut Liver. 2018 Jan 3. [Epub ahead of print]

3. Nieto J, Khaleel H, Challita Y, Jimenez M, Baron TH, Walters L, et al. EUS-guided fine-needle core liver biopsy sampling using a novel 19-gauge needle with modified 1 pass, 1 actuation wet 
suction technique. Gastrointest Endosc. 2018;87:469-475.

4. Shah ND, Sasatomi E, Baron TH. Endoscopic Ultrasoundguided Parenchymal Liver Biopsy: Single Center Experience of a New Dedicated Core Needle. Clin Gastroenterol Hepatol. 2017; 15:784-786.

5. Schulman AR, Thompson CC, Odze R, Chan WW, Ryou M. Optimizing EUS-guided liver biopsy sampling: comprehensive assessment of needle types and tissue acquisition techniques. Gastrointest Endosc. 2017;85:419-426.

6. DiMaio CJ, Kolb JM, Benias PC, Shah H, Shah S, Haluszka $\mathrm{O}$, et al. Initial experience with a novel EUS-guided core biopsy needle (SharkCore): results of a large North American multicenter study. Endosc Int Open. 2016;4:E974-E979.

7. Rodrigues-Pinto E, Jalaj S, Grimm IS, Baron TH. Impact of EUS-guided fine-needle biopsy sampling with a new core needle on the need for onsite cytopathological assessment: a preliminary study. Gastrointest Endosc. 2016;84:1040-1046.

8. Inoue T, Okumura F, Mizushima T, Nishie H, Iwasaki H, Anbe K, et al. Assessment of Factors Affecting the Usefulness and Diagnostic Yield of Core Biopsy Needles with a Side Hole in Endoscopic Ultrasound-Guided Fine-Needle Aspiration. Gut Liver. 2016;10:51-57.

9. Sandulescu L, Padureanu V, Dumitrescu C, Braia N, Streba CT, Gheonea DI, et al. A pilot study of real time elastography in the differentiation of focal liver lesions. Curr Health Sci J. 2012;38:32-35.

10. Hirooka Y, Itoh A, Kawashima H, Ohno E, Itoh Y, Nakamura $\mathrm{Y}$, et al. Contrast-enhanced endoscopic ultrasonography in digestive diseases. J Gastroenterol. 2012;47:1063-1072.

11. Nguyen P, Feng JC, Chang KJ. Endoscopic ultrasound (EUS) and EUS-guided fine-needle aspiration (FNA) of liver lesions. Gastrointest Endosc. 1999;50:357-361.

12. Prachayakul V, Aswakul P, Kachintorn U. EUS guided fine needle aspiration cytology of liver nodules suspicious for malignancy: yields, complications and impact on management. J Med Assoc Thai. 2012;95 Suppl 2:S56-S60.

13. tenBerge J, Hoffman BJ, Hawes RH, Van Enckevort C, Giovannini M, Erickson RA, et al. EUS-guided fine needle aspiration of the liver: indications, yield, and safety based on an international survey of 167 cases. Gastrointest Endosc. 2002;55:859-862.

14. Rameshbabu CS, Wani ZA, Rai P, Abdulqader A, Garg S, Sharma M. Standard imaging techniques for assessment of portal venous system and its tributaries by linear endoscopic ultrasound: a pictorial essay. Endosc Ultrasound. 2013;2:16-34.

15. Magalhães J, Monteiro S, Xavier S, Leite S, de Castro FD, Cotter J. Endoscopic ultrasonography - emerging applications in hepatology. World J Gastrointest Endosc. 2017;9:378-388.

16. Hammoud GM, Almashhrawi A, Ibdah JA. Usefulness of endoscopic ultrasound-guided fine needle aspiration in the diagnosis of hepatic, gallbladder and biliary tract Lesions. World J Gastrointest Oncol. 2014;6:420-429.

17. DeWitt J, LeBlanc J, McHenry L, Ciaccia D, Imperiale T, Chappo J, et al. Endoscopic ultrasound-guided fine needle aspiration cytology of solid liver lesions: a large single-center experience. Am J Gastroenterol. 2003;98:1976-1981.

18. Hollerbach S, Reiser M, Topalidis T, König M, Schmiegel W. Diagnosis of hepatocellular carcinoma (HCC) in a high-risk patient by using transgastric EUS-guided fine-needle biopsy (EUS-FNA). Z Gastroenterol. 2003;41:995-998.

19. McGrath K, Brody D, Luketich J, Khalid A. Detection of unsuspected left hepatic lobe metastases during EUS staging of cancer of the esophagus and cardia. Am J Gastroenterol. 2006; 101:1742-1746.

20. Crowe DR, Eloubeidi MA, Chhieng DC, Jhala NC, Jhala D, Eltoum IA. Fine-needle aspiration biopsy of hepatic lesions: computerized tomographic-guided versus endoscopic ultrasoundguided FNA. Cancer. 2006;108:180-185.

21. Singh P, Mukhopadhyay P, Bhatt B, Patel T, Kiss A, Gupta R, et al. Endoscopic ultrasound versus CT scan for detection of the metastases to the liver: results of a prospective comparative study. J Clin Gastroenterol. 2009;43:367-373.

22. Lee YN, Moon JH, Kim HK, Choi HJ, Choi MH, Kim DC, et al. Usefulness of endoscopic ultrasound-guided sampling using core biopsy needle as a percutaneous biopsy rescue for diagnosis of solid liver mass: Combined histological-cytological analysis. J Gastroenterol Hepatol. 2015;30:1161-1166.

23. Oh D, Seo DW, Hong SM, Song TJ, Park DH, Lee SS, et al. Endoscopic ultrasound-guided fine-needle aspiration can target right liver mass. Endosc Ultrasound. 2017;6:109-115.

24. Singh P, Erickson RA, Mukhopadhyay P, Gopal S, Kiss A, Khan A, et al. EUS for detection of the hepatocellular carcinoma: results of a prospective study. Gastrointest Endosc. 2007;66:265-273.

25. Burrel M, Llovet JM, Ayuso C, Iglesias C, Sala M, Miquel $\mathrm{R}$, et al. MRI angiography is superior to helical CT for detection of HCC prior to liver transplantation: an explant correlation. Hepatology. 2003;38:1034-1042.

26. Awad SS, Fagan S, Abudayyeh S, Karim N, Berger DH, Ayub K. Preoperative evaluation of hepatic lesions for the staging of hepatocellular and metastatic liver carcinoma using endoscopic ultrasonography. Am J Surg. 2002;184:601-604; discussion 604-605. 27. Bhatia V, Hijioka S, Hara K, Mizuno N, Imaoka H, Yamao $\mathrm{K}$. Endoscopic ultrasound description of liver segmentation and anatomy. Dig Endosc. 2014;26:482-490.

28. Parekh PJ, Majithia R, Diehl DL, Baron TH. Endoscopic ultrasound-guided liver biopsy. Endosc Ultrasound. 2015;4:85-91.

29. Polkowski M, Larghi A, Weynand B, Boustière C, Giovannini $\mathrm{M}$, Pujol B, et al. Learning, techniques, and complications of endoscopic ultrasound (EUS)-guided sampling in gastroenterology: European Society of Gastrointestinal Endoscopy (ESGE) Technical Guideline. Endoscopy. 2012;44:190-206.

30. Bhatia V, Varadarajulu S. Endoscopic ultrasonography-guided tissue acquisition: How to achieve excellence. Dig Endosc. 2017;29:417-430.

31. Wani S, Gupta N, Gaddam S, Singh V, Ulusarac O, Romanas $\mathrm{M}$, et al. A comparative study of endoscopic ultrasound guided fine needle aspiration with and without a stylet. Dig Dis Sci. 2011;56:2409-2414.

32. Khan MA, Grimm IS, Ali B, Nollan R, Tombazzi C, Ismail $\mathrm{MK}$, et al. A meta-analysis of endoscopic ultrasound-fine-needle aspiration compared to endoscopic ultrasound-fine-needle biopsy: diagnostic yield and the value of onsite cytopathological assessment. Endosc Int Open. 2017;5:E363-E375.

33. Wittmann J, Kocjan G, Sgouros SN, Deheragoda M, Pereira SP. Endoscopic ultrasound-guided tissue sampling by combined fine needle aspiration and trucut needle biopsy: a prospective study. Cytopathology. 2006;17:27-33.

34. Stavropoulos SN, Im GY, Jlayer Z, Harris MD, Pitea TC, Turi GK, et al. High yield of same-session EUS-guided liver biopsy by 19-gauge FNA needle in patients undergoing EUS to exclude biliary obstruction. Gastrointest Endosc. 2012;75:310-318.

35. Gor N, Salem SB, Jakate S, Patel R, Shah N, Patil A. 
Histological adequacy of EUS-guided liver biopsy when using a 19-gauge non-Tru-Cut FNA needle. Gastrointest Endosc. 2014;79:170-172.

36. Prasad P, Schmulewitz N, Patel A, Varadarajulu S, Wildi SM, Roberts $\mathrm{S}$, et al. Detection of occult liver metastases during EUS for staging of malignancies. Gastrointest Endosc. 2004;59:49-53. 37. Fujii-Lau LL, Abu Dayyeh BK, Bruno MJ, Chang KJ, DeWitt JM, Fockens P, et al. EUS-derived criteria for distinguishing benign from malignant metastatic solid hepatic masses. Gastrointest Endosc. 2015;81:1188-1196.e1-e7.

38. Bissonnette J, Paquin S, Sahai A, Pomier-Layrargues G. Usefulness of endoscopic ultrasonography in hepatology. Can J Gastroenterol. 2011;25:621-625.

39. Thuluvath PJ. EUS-guided FNA could be another important tool for the early diagnosis of hepatocellular carcinoma. Gastrointest Endosc. 2007;66:274-276.

40. Kimura H, Matsubayashi H, Fukutomi A, Asakura K, Sasaki $\mathrm{K}$, Yamaguchi $\mathrm{Y}$, et al. Lymph node metastasis diagnosed by EUS-FNA in four cases with hepatocellular carcinoma. Clin Res Hepatol Gastroenterol. 2011;35:237-240.

41. Das A, Sivak MV Jr, Chak A. Cervical esophageal perforation during EUS: a national survey. Gastrointest Endosc.
2001;53:599-602.

42. Jenssen C, Alvarez-Sánchez MV, Napoléon B, Faiss S. Diagnostic endoscopic ultrasonography: assessment of safety and prevention of complications. World J Gastroenterol. 2012;18:4659-4676.

43. ASGE Standards of Practice Committee, Early DS, Acosta RD, Chandrasekhara V, Chathadi KV, Decker GA, et al. Adverse events associated with EUS and EUS with FNA. Gastrointest Endosc. 2013;77:839-843.

44. Wang KX, Ben QW, Jin ZD, Du YQ, Zou DW, Liao Z, et al. Assessment of morbidity and mortality associated with EUS-guided FNA: a systematic review. Gastrointest Endosc. 2011;73:283-290.

45. Jovani M, Abidi WM, Lee LS. Novel fork-tip needles versus standard needles for EUS-guided tissue acquisition from solid masses of the upper GI tract: a matched cohort study. Scand J Gastroenterol. 2017;52:784-787.

46. Varadarajulu S, Ginnetti L, Peetermans J, Rousseau M, Hasan M, Hawes R. Meta-Analysis Comparing Rates of Complications between the standard $19 \mathrm{G}$ and $22 / 25 \mathrm{G}$ needles for EUS-Guided FNA of Pancreatic Lesions. Gastrointest Endosc. 2013;77 Suppl:AB405. 